\title{
DEVELOPMENT OF LARSON'S PROBLEMS SOLVING PATTERNS WITH "IDEAL" STRATEGIES
}

\author{
${ }^{1)}$ Junarti, ${ }^{2)}$ Stevanus Budi Waluyo, ${ }^{3)}$ Rochmad \\ ${ }^{1}$ FPMIPA, IKIP PGRI Bojonegoro \\ email: Junarti_s@yahoo.com \\ ${ }^{2}$ FMIPA, PPS UNNES \\ email: s.b.waluya.math@gmail.com \\ ${ }^{2}$ FMIPA, PPS UNNES \\ email: rochmad.math@gmail.com
}

\begin{abstract}
Mathematical Problem-solving is taught to improve students' high-order thinking skills. A heuristic problem-solving strategy is used to find different Problemsolving. This research is to: 1) describe the student's Problem-solving ability profile in finding the pattern of algebra solving through the "IDEAL" (Identify Define Explore Act Look back) strategy by developing Larson's Problem-solving pattern, 2) measuring the extent of the pattern can be formed by using "IDEAL". Finding patterns is part of the first heuristic strategy. The research method used a qualitative approach with descriptive analysis. Problems conveyed to students are done in pairs of two people, with the consideration that more discussion opportunities with friends make it possible to get more than five troubleshooting as Larson puts it. The results showed that: 1) profile Problem-solving ability found pattern with "IDEAL" strategy from student got result that from problem given to 20 student group can help solve algebra Problem-solving; 2) there are four kinds of Problem-solving patterns consisting of 3 Larson model Problem-solving patterns and one Problem-solving pattern using geometry sequence pattern.
\end{abstract}

Keyword: Problem-solving Pattern, Heuristic, “IDEAL” Strategy

\begin{abstract}
Abstrak: Pemecahan masalah matematika diajarkan untuk meningkatkan kemampuan pemikiran tingkat tinggi mahasiswa. Strategi pemecahan masalah heuristic digunakan untuk menemukan pemecahan masalah yang berbeda. Penelitian ini untuk: 1) menggambarkan profil kemampuan pemecahan masalah mahasiswa dalam menemukan pola pemecahan aljabar melalui strategi "IDEAL" (Identify Define Explore Act Look back) dengan mengembangkan pola pemecahan masalah Larson, 2) mengukur sejauhmana pola yang dapat dibentuk mahasiswa dengan menggunakan strategi "IDEAL". Menemukan Pola merupakan bagian dari strategi heuristik yang pertama. Metode penelitiannya menggunakan pendekatan kualitatif dengan analisis deskriptif. Masalah yang disampaikan kepada mahasiswa dikerjakan secara berpasangan dua orang, dengan pertimbangan bahwa semakin banyak peluang diskusi dengan teman memungkinkan untuk mendapatkan pemecahan masalah lebih dari lima seperti yang disampailan Larson. Hasil penelitian menunjukkan bahwa: 1) profil kemampuan pemecahan masalah menemukan pola dengan strategi "IDEAL" dari mahasiswa diperoleh hasil bahwa dari masalah yang diberikan kepada 20 kelompok mahasiswa dapat membantu menyelesaikan pemecahan masalah aljabar; 2) terdapat empat macam pola pemecahan masalah yang terdiri dari 3 pola pemecahan masalah model Larson dan satu pola pemecahan masalah dengan menggunakan pola barisan geometri.
\end{abstract}

Kata Kunci: Pola pemecahan masalah, Heuristik, Strategi "IDEAL" 


\section{INTRODUCTION}

Mathematical Problem-solving becomes part of mathematics learning, Problemsolving requires high thinking. Each subject has a "problem" and its solving goal to be achieved, to achieve its goal of thought (Bookhart, 2010).

In mathematics, especially in algebra, is inseparable from the problem that must be solved and searched solution. Good Problemsolving identifies what the problem is, what the bottleneck is, and what solutions make it possible to solve it. Good problem solvers have at least one solution of some existing solutions (Bookhart, 2010). For good problem solvers on complex problems can prioritize and evaluate the relative effectiveness of different solution strategies (Marzano et al., 1993; in Bookhart, 2010). One of the different solution strategies is to use a heuristic strategy.

Heuristics is a way of solving problems in some areas of mathematics, engineering and informatics, among others, heuristics as well as solving optimization problems (Kusumadewi, 2005), heuristics is also a method in finding the shortest route in the study of information technology (Mutakhiroh, 2007), heuristik also used in evaluation in computer applications (Savitri, 2015). Heuristics used by engineers and scientists in solving design-type problems are non-algorithmic empirical tricks and tools (Sickafus, 2004). The application of heuristic strategies for mathematics studies has not been widely developed.

According to Larson (1983), a strategy or tactic in Problem-solving is called heuristic. Heuristics of mathematical Problem-solving are twelve solving strategies:

1. Search for Pattern

2. Draw a Figure

3. Formulating an equivalent problem

4. Modify the problem
5. Choosing effective notation

6. Exploit symmetry

7. Divide into cases

8. Work backward

9. Argue by contradiction

10. Check for parity

11.Consider extreme case

\section{Generalize}

The workings of Bransford and Stein's Problem-solving (1984, in Bookhart, 2010) classifies into five phases called "IDEAL Problem Solver", ie;

1. Identify the problem

2. Define and represent the problem

3. Explore possible strategies

4. Act on the strategies

5. Look back and evaluate the effects of your activities

Larson (1983) writes several solutions to algebraic problems using the first heuristic strategy of finding patterns. There are five patterns of Problem-solving in determining the subsets of a given set. In this study, the mathematical problems studied were focused on algebra materials for sixth-semester students (6). Based on Piaget's theory, the age of students about 17 years and above fall into the category of formal thinking, meaning that cognitive students have been able to think high level. Thus the student is theoretically capable of using Problemsolving strategies more than one way in different ways.

Student troubleshooting performance in math is often bad. The findings show that students' algebraic problem-solving performance has no correlation with the types of cognitive (deep and shallow) strategies (Bayata and Tarmizi, 2010). In this research, it will be taken into consideration in determining the object to be studied.

The focus of this study is on the ability to use heuristic strategies in the first way that is "making patterns" in algebra Problemsolving. 
follows:

Statement of the problems are as

1. What is the profile of Problem-solving skills of Mathematics Education Study student of IKIP PGRI Bojonegoro in finding pattern through "IDEAL" strategy by developing Larson Problem-solving pattern?

2. How far a pattern that can be formed by students of Mathematics Education Study Program IKIP PGRI Bojonegoro using the "IDEAL" strategy?

\section{RESEARCH METHOD}

The research method used with qualitative. Qualitative methods are used to measure the ability to find the Problemsolving pattern correctly with a descriptive test. And qualitative methods are used to analyze the extent and how many patterns students can shape on Problem-solving with the "IDEAL" strategy

As this research develops an existing problem, the proposed Problem-solving instrument focuses one problem on the set of numbers adopted from Larson (1983). Then the instrument is done by each group of two students, with consideration in order to find more different Problem-solving patterns from Larson's settlement. Students are divided into random groups without looking at cognitive abilities.

Assessment of Problem-solving patterns is used IDEAL strategy with five components in formulated indicators as follows with Level/ Course: Student/ Algebra; highlights: The set; semester: VI / Odd; Time Allocation: 120 minutes.

Table 1: Lattice Instruments

\begin{tabular}{lll}
\hline $\begin{array}{c}\text { Number of } \\
\text { Question }\end{array}$ & \multicolumn{1}{c}{ Indicators Measured } & Indicator \\
\hline 1. & $\begin{array}{l}\text { Given an algebraic question of subsets that can be formed } \\
\text { from a finite set n, with n members of the set of native } \\
\text { numbers. Students can understand the problem, plan }\end{array}$ & (PS1), (PS2), \\
& $\begin{array}{l}\text { Problem-solving, carry out Problem-solving planning, re- } \\
\text { examine Problem-solving, and answer problem in the form } \\
\text { of pattern (pattern) }\end{array}$ & (PS5), (PS6), \\
& (PS7), (PS8),
\end{tabular}

Capability Indicators Find Patterns in Problem-solving Algebra with IDEAL Strategy (P).

The ability to measure on finding patterns in troubleshooting is:

1. Identify problems to be solved, including ability:

a. expressing the question in terms of language and subject concept of mathematical problems to be solved (PS1)

b. express by writing down what is known and what is asked correctly and clearly (PS2) c. write down the steps that will be used to solve it (PS3)

2. Define (describe) and describe the problem, including ability:

a. explains by making a symbol or a mathematical model of a problem situation (PS4)

b. create an image framework or flow framework of the problem (PS6)

3. Investigate possible strategies for problem-solving planning, including the ability to:

a. choose a strategy for solving algebraic models or problems (PS7) 
b. implement strategies to solve algebra problems significantly (PS7)

4. Perform a problem-solving strategy by writing the way to be done (PS8)

5. Reviewing and evaluating the effects of activity by following capabilities:

a. describe according to the original problem (PS9).

b. interpreting the results correctly (PS10).

RESULTS AND DISCUSSION
The test was done in a group consisting of two randomly selected students. Conducted in groups with consideration to allow to bring up many different ways or solutions from the five ways that Larson delivered. Students are given the freedom of discussion to find solutions to Problemsolving, but still under the supervision of lecturers. From the problem-solving data provided for 120 minutes to 20 groups of students obtained the following results

Table 2: Profile of Problem-solving Patterns with "IDEAL" Strategy

\begin{tabular}{|c|c|c|c|c|c|c|c|}
\hline Group & $\begin{array}{c}\text { Solution } \\
1\end{array}$ & $\begin{array}{c}\text { Solution } \\
2\end{array}$ & $\begin{array}{c}\text { Solution } \\
\mathbf{3}\end{array}$ & $\begin{array}{c}\text { Solution } \\
4\end{array}$ & $\begin{array}{c}\text { Solution } \\
5\end{array}$ & $\begin{array}{c}\text { Other } \\
\text { Solution }\end{array}$ & Tota \\
\hline 1. & $V$ & $V$ & & & & V & 3 \\
\hline 2. & $V$ & $V$ & & $V$ & & $V$ & 4 \\
\hline 3. & $V$ & $V$ & & $V$ & & & 3 \\
\hline 4. & $V$ & & & $V$ & & $V$ & 3 \\
\hline 5. & $V$ & & & $v$ & & & 2 \\
\hline 6. & $V$ & & & $V$ & & & 2 \\
\hline 7. & $V$ & & & $V$ & & & 2 \\
\hline 8. & $V$ & & & $V$ & & & 2 \\
\hline 9. & $V$ & & & $V$ & & & 2 \\
\hline 10. & $V$ & & & $V$ & & & 2 \\
\hline 11. & $V$ & & & $V$ & & & 2 \\
\hline 12. & $V$ & & & $V$ & & & 2 \\
\hline 13. & $V$ & & & $V$ & & & 2 \\
\hline 14. & $V$ & & & $V$ & & & 2 \\
\hline 15. & $V$ & & & $V$ & & & 2 \\
\hline 16. & $V$ & & & $V$ & & & 2 \\
\hline 17. & $V$ & & & $V$ & & & 2 \\
\hline 18. & $V$ & & & $V$ & & & 2 \\
\hline 19. & $V$ & & & $V$ & & & 2 \\
\hline 20. & $V$ & & & $V$ & & & 2 \\
\hline Total & 20 & 3 & $\mathbf{0}$ & 19 & & 3 & \\
\hline
\end{tabular}

Note: Solutions 1 through 5 are Larson's solutions

From the results in table 2 above, based on observations during the ongoing Problemsolving occurs communication and discussion in each group take place optimally. Of the 20 groups working on the problem after the analysis it was found that a randomly selected group of students was able to perform two Problem-solving solutions using one, and solution 2 using the sequence concept in finding the number of subsets of $n$ elements. 19 other groups can only one solution 2 only. From one group of students who have other solutions 3 groups then interviewed and stated that obtained from the 
solution itself by trying to pattern the line. And 2 groups of students who had no other answers were interviewed claimed that they could not think of an unprecedented solution.

The results showed that:

a. the students' Problem-solving skills profile in finding patterns through the "IDEAL" strategy can help facilitate the solving of algebraic problems, illustrated by 20 groups of students capable of performing two solutions;

b. the number of Problem-solving patterns that the student can construct is the result that 20 groups work on solutions 1, 3 groups work on solution 2, 19 groups work on solution 4 , and 3 groups work on other solutions;

c. 1 group has 4 types of solutions (solution 1 , solution 2, solution 4, and other solutions), other solutions have not fulfilled the correct solution to the wrong solution;

d. 3 groups have 3 types of solutions consisting of:

1) 1 group has solution 1 , solution 2 , and solution 4

2) 1 group has solution 1 , solution 4 , and other solution but wrong;

3) 1 group has solution 1 , solution 2 , and other correct solutions (other solutions are made by finding through tribe geometric sequence).

So there are 3 student solutions that are the same as Larson's solution and 3 other solutions are not the same as Larson's solution but two other solutions are wrong and 1 other solution is true. Thus there is only one additional solution from Larson's solution that is in the form of geometry sequence pattern as follows figure 1 .

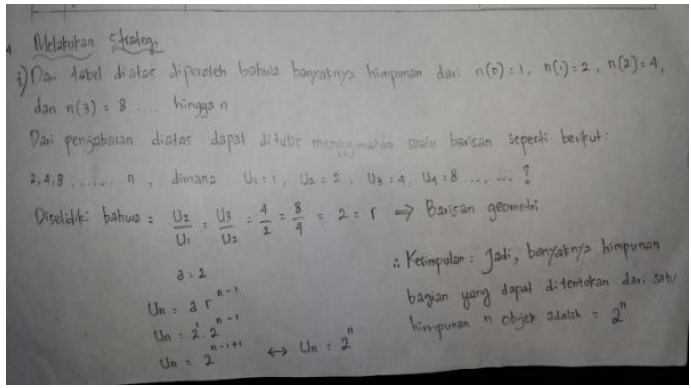

Figure 1 Student's answer

\section{Discussion}

When students encounter math problems using the "IDEAL" stages, the steps are directed towards building a solution in the way that students have. Yet again if the solution strategy is not presented more specifically it will have difficulty to direct students' thinking in finding solutions to solving it. Finding patterns in Problemsolving is a workaround that helps make finding solutions easier, since it will involve smaller and simpler numbers, especially on algebraic issues will be more helpful in finding solutions. As in Anderson's (2012) study involving multivariate patterns combined with the Hidden Markov Model algorithm to trace thinking when solving complex problems and algebra problems.

Finding patterns in Problem-solving lies in finding the rules of the pattern (Orton, 2006). The rules of the pattern require visualization ability, so that it will find an easily understood strategy, the pattern can be a pattern of geometric sequences or geometric structures, as in Wilkie and Clarke's (2016) research that through visualizing the same geometric structure with explicit generalizations as equations different and equal symbols can have implications in the teaching of functional thinking in algebra in secondary schools.

In learning mathematics as a supporter of psychology, the pattern is one of the foundations, all of the universe depends on the pattern in understanding many things 
(Orton, 2006). The usefulness of patterns in life as in the study of collaborative work patterns of 133 participants from universitylevel courses designed to develop Problemsolving skills that can be done (Wismath, Shelly L.; Orr, Doug; 2015). For many adults, if the structure can not become clear and significant, then the role of the pattern will lead to a thorough understanding of the pattern and its relationship (Orton, 2006).

Finding patterns is the first heuristic solution, heuristics are more than one solution and require divergent thinking (Orton, 2006). The process of mathematics is a heuristic teacher because with a mathematical process it can explore a rich problem by completing a task, analyzing examples of student work, designing key solutions, and modifying tasks (Meagher, Edwards, Ozgun-Koca; 2013).

Some research on heuristics related to Problem-solving includes research on the use of heuristics to show the value of visualspatial representation and heuristic Problemsolving of mathematical words in high school (Kribbs, Elizabeth \& Rogowsky, Beth; 2016); groups subjected to scientific heuristic methods are better than those given direct instruction on the topic of Algebra (Calucag, Lina S, 2016); by transforming student heuristics as a strategy for Problem-solving to find solutions to Problem-solving schemes (Koichu, Berman, Abraham and Moore, Michael, 2003); the use of heuristic strategies can provide instruction on Problem-solving so as to improve student outcomes/performance in mathematical Problem-solving (Kusdinar, Uus, 2016)

1. Problem-solving

For problems that require high-order thinking, the solution strategy is not immediately apparent. Problems that require high-level thinking are nonroutine issues (Bookhart, 2010).
The types of problems according to Bookhart (2010) are grouped into two, ie

a. Types of structured and unstructured issues. The more decisions that are open to students, the less structured the problem.

Unstructured issues are more typical of real-life problems. A highly structured problem allows teachers to better control the content of student work. Teachers can use different types of structures, but they must recognize the type of problem they are using and make sure the problem requires specific problemsolving skills that they want to value.

b. Open-ended problem

Problems in each circuit are identical except for endpoints. One group of students has conventional directions: "Find $\mathrm{x}$," where $\mathrm{x}$ is a certain angular size. The instructions for another group of students read: "Find all unknown angles." Ayres calls this "free-purpose" issue, but it means "purpose" in the sense of "one needed answer" to the problem. Teachers will call this "unstructured" problem and will say they have an understanding of student learning goals and use a geometry point of view.

McClymer and Knoles (1992, in Bookhart, 2010) observe that students without skills know what is relevant and what does not fit the task rather than learn from it. Two of these coping mechanisms involve students who produce what McClymer and Knole call "blobs" or "shapes." A clot is a collection of information that is shoveled without the logic or basic explanation. Students can collect data, reproduce a lot of information with little or no thought.

To solve high-level math problems requires a strategy that is not immediately apparent, and usually not a routine problem (Brookhart, 2010). Non-routine problems 
such as stories, phenomena or events, illustrations of images or puzzles. Such problems are called mathematical problems because they contain a mathematical concept (Lidinilah, 2012).

The ability to solve problems is very important, NTCM (Romberg, 1994: 288), emphasizes that problem-solving skills as an important aspect of making students become skilled in solving mathematical problems.

Algebraic problems were written by Larson (1993) about the Problem-solving pattern of the following problem: prove that the set $\mathrm{n}$ (different) elements have the same $2 n$ subsets.

a. How many subsets can be formed from a set of $n$ objects?

b. Prove or disprove: A set with $\mathrm{n}$ elements has $2^{\mathrm{n}}$ subsets!

From this problem, Larson (1993), writes the five patterns presented. Five patterns of solutions adopted from Larson see table 1 below.

Solution 1. We begin by examining what happens when the set contains $0,1,2,3$ elements; the results are shown in the following table.

Table 3: Solution 1

\begin{tabular}{lllc}
\multicolumn{2}{c}{$\begin{array}{c}\text { Elements } \\
\text { of } S\end{array}$} & Subsets of $S$ & $\begin{array}{c}\text { Number of } \\
\text { subsets of } S\end{array}$ \\
\hline 0 & none & $\emptyset$ & 1 \\
1 & $x_{1}$ & $\emptyset,\left\{x_{1}\right\}$ & 2 \\
2 & $x_{1}, x_{2}$ & $\emptyset,\left\{x_{1}\right\},\left\{x_{2}\right\},\left\{x_{1}, x_{2}\right\}$ & 4 \\
3 & $x_{1}, x_{2}, x_{3}$ & $\emptyset,\left\{x_{1}\right\},\left\{x_{2}\right\},\left\{x_{1}, x_{2}\right\}$ & 8 \\
& & $\left\{x_{3}\right\},\left\{x_{1}, x_{3}\right\},\left\{x_{2}, x_{3}\right\},\left\{x_{1}, x_{2}, x_{3}\right\}$ &
\end{tabular}

Our purpose in constructing this table is not only to verify the result, but also to look for patterns that might suggest how to proceed in the general case. Thus, we aim to be as systematic as possible. In this case, notice when $\mathrm{n}=3$, we have listed first the subsets of $\left\{x_{1}, x_{2}\right\}$ and then, in the second line, each of these subsets augmented by the element $x_{3}$. This is the key idea that allows us to proceed to higher values of n. For example, when $\mathrm{n}=4$, the subsets of $\mathrm{S}=$ $\left\{x_{1}, x_{2}, x_{3}, x_{4}\right\}$ are the eight subsets of $\left\{x_{1}, x_{2}, x_{3}\right\}$ (shown in the table) together with the eight formed by adjoining $x_{4}$ to each of these. These sixteen subsets constitute the entire collection of possibilities; thus, a set with 4 elements has $2^{4}(=16)$ subsets.

Solution 2. Another way to present the idea of the last solution is to argue as follows. For each $n$, let $A_{n}$ denote the number of (different) subsets of a set with $\mathrm{n}$ (different) elements. Les $\mathrm{S}$ be a set with $\mathrm{n}+1$ elements, and designate one of its elements by $\mathrm{x}$. There is a one-to-one correspondence between those subsets of $\mathrm{S}$ which do not contain $\mathrm{x}$ and those subsets that do contain $\mathrm{x}$ (namely, a subset $\mathrm{T}$ of the former type corresponds to $T \cup\{x\})$. The former types are all subsets of $S-\{x\}$, a set with $n$ elements, and therefore, it must be the case that

$$
A_{n+1}=2 A_{n}
$$

This recurrence relation, true for $\mathrm{n}=$ $0,1,2,3, \ldots$ combined with the fact that $\mathrm{A}_{0}=$ 1 , implies that $A_{n}=2^{n} .\left(A_{n}=2 A_{n-1}=\right.$ $2^{2} A_{n-2}=\cdots=2^{n} A_{0}=2^{n}$ )

Solution 3. Another systematic enumeration of subsets can be carried out by constructing a "tree". For the case $\mathrm{n}=3$ and $S=\{a, b, c\}$, the tree is as shown below: 


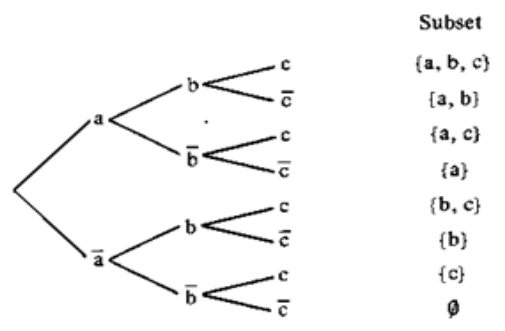

Figure 2 Solution 3

Each branch of the tree corresponds to a distinct subset of $\mathrm{S}$ (the bar over the name of the element means that it is not included in the set corresponding to that branch). The tree is constructed in three stages, corresponding to the three elements of $\mathrm{S}$. Each element of S leads to two possibilities; either it is in the subset or it is not, and these choices are represented by two branches. As each element is considered, the numbe of branches double.

Thus, for a three-element set, the number of branches is $2 \times 2 \times 2=8$. For an n-element set the number of branches is

$$
\underbrace{2 \times 2 \times \cdots \times 2}_{n}=2^{n} ;
$$

Thus, a set with $\mathrm{n}$ elements has $2^{\mathrm{n}}$ subsets.

Solution 4. Suppose we enumerate subsets according to their size. For example, when $\mathrm{S}=\{a, b, c, d\}$, the subsets are

Tabel 4: Solution 4

\begin{tabular}{ccc}
\hline $\begin{array}{c}\text { Number of } \\
\text { elemen }\end{array}$ & $\begin{array}{c}\text { Number of } \\
\text { subsets }\end{array}$ \\
\hline 0 & $\emptyset$ & 1 \\
\hline 1 & $\{a, b\},\{a, c\},\{a, d\},\{b, c\},\{b, d\},\{c, d\}$ & 4 \\
\hline 2 & $\{a, b, c\},\{a, b, d\},\{a, c, d\},\{b, c, d\}$ & 6 \\
\hline 3 & $\{a, b, c, d\}$ & 1 \\
\hline 4 & $(x+y)^{n}=\sum_{k=0}^{n}\left(\begin{array}{l}n \\
k\end{array}\right) x^{k} y^{n-k}$
\end{tabular}

Upon setting $\mathrm{x}=1$ and $\mathrm{y}=1$

Solution 5. Another systematic beginning is illustrated in Table 1.1., which lists the subsets of $\mathrm{S}=\left\{x_{1}, x_{2}, x_{3}\right\}$. To understand the pattern here, notice the correspondence of subscripts in the leftmost column and the occurrence

$$
\begin{aligned}
& \text { No. of subsets of S } \\
& =\sum_{\mathrm{k}=0}^{\mathrm{n}} \text { (No. ofsubsets of S with k element) } \\
& =\sum_{k=0}^{n}\left(\begin{array}{l}
n \\
k
\end{array}\right)=2^{n}
\end{aligned}
$$$$
\text { occurrence }
$$

The final step in this chain of equalities follows from the binomial theorem,

Table 2

\begin{tabular}{cccc}
\hline Subset & Triple & Binary Number & Decimal Number \\
\hline$\varnothing$ & $(0,0,0)$ & 0 & 0 \\
\hline$\left\{x_{3}\right\}$ & $(0,0,1)$ & 1 & 1 \\
\hline$\left\{x_{2}\right\}$ & $(0,1,0)$ & 10 & 2 \\
\hline$\left\{x_{2}, x_{3}\right\}$ & $(0,1,1)$ & 11 & 3 \\
\hline$\left\{x_{1}\right\}$ & $(1,0,0)$ & 100 & 4 \\
\hline$\left\{x_{1}, x_{3}\right\}$ & $(1,0,1)$ & 101 & 5 \\
\hline$\left\{x_{1}, x_{2}\right\}$ & $(1,1,0)$ & 110 & 6 \\
\hline
\end{tabular}




\begin{tabular}{llll}
\hline$\left\{x_{1}, x_{2}, x_{3}\right\}$ & $(1,1,1)$ & 111 & 7 \\
\hline
\end{tabular}

To understand the pattern here, consider the subscript correspondence in the leftmost column and its occurrence of 1's in the second column of triples. Specifically, if A is a subset of $\mathrm{S}=\left\{x_{1}, x_{2}, \ldots, x_{n}\right\}$, define $\mathrm{a}_{\mathrm{i}}$, for $\mathrm{i}=1,2, \ldots, \mathrm{n}$, by

$$
a_{i}=\left\{\begin{array}{l}
1, j i k a a_{i} \in A \\
0, j i k a \\
a_{i} \notin A
\end{array}\right.
$$

It is clear that we can now identify a subset $\mathrm{A}$ of $\mathrm{S}$ with $\left\{x_{1}, x_{2}, \ldots, x_{n}\right\}$, an n-tuple of 0 's and 1's. Conversely, each such n-tuple will correspond to a unique subset of $\mathrm{S}$. Thus, the number of subsets of $S$ is equal to the number of n-tuples of 0's and 1's. This latter set is obviously in one-to-one correspondence with the set of nonnegative binary numbers less than $2^{\mathrm{n}}$ corresponds to exactly one subset of $\mathrm{S}$, and conversely. Therefore, it must be the case that $\mathrm{S}$ has $2^{\mathrm{n}}$ subsets.

In this study, with the same problem from Larson problem, how is the pattern that can be formed by the students of Mathematics Department using "IDEAL" strategy?

Almost all problem solvers start their analysis by perceiving the problem, convincing themselves that the results make sense. This is best done by examining the most immediate special case (Bookhart, 2010). When this exploration is done systematically, basic calculation skills are a significant predictor of mathematical problem solving across samples (Decker and Roberts, 2015)

\section{Problem-solving pattern}

The pattern is an important problemsolving tool in the working order of algebraic material numbers from two perspectives of justice since algebra is considered the key to mathematical literacy. (Zevenbergen, 2004: Orton, 2006).
Furthermore, Zevenbergen (2004, 234) explains that in general learning algebra thinking is supported through the work of patterns and relationships, so that in teaching at the basic level has a strong emphasis on the pattern so that students can prepare algebra thinking. For many people, it is a problem because they do not have a good starting algebra. Original algebraic thinking begins in the exploration of patterns and patterns of numbers in preschoolers and the early years of primary school

Algebraic thinking has three key elements as the same change. This success may be one of the most difficult aspects of mathematical learning, partly because of the way it teaches in numbers (Zevenbergen, 2004)

There are 3 different aspects of the pattern namely:

a. repetition pattern,

b. growing patterns and

c. the pattern of numbers (Zevenbergen, 2004).

Teachers should organize a learning experience that progressively expands students' thinking, it is important to allow time to improve, explain or expand the pattern because there may be other ways to look at patterns imagined by teachers when observing students working with patterns so as to provide a rationale and enabling teachers to plan better teaching (Zevenbergen, 2004).

Blurne and Heckman (2000, in Zevenbergen 2004) noted that students are more likely to be able to continue the pattern rather than incorporating missing elements. It is important for students to experience both linear patterns in one direction only, as well as the two-way pattern as in the initial experience of the 
pattern in two opposite directions (Zevenbergen, 2004). The pattern activity a pattern (especially figural, but also numerical) and suspect the function-based relationships that link variables (Ferrara and Sinclair, 2016)

In teaching patterns it is very important to focus on students who develop a language that suits the pattern so that they can identify certain elements in the pattern, eg what will be the fifth term? Repetition patterns are usually introduced in linear form. Once students get used to this format, they can work with a format where repetition runs more in one direction. The study of patterns can often involve geometric patterns and patterns in cultural practices such as quilting, puzzles, and so forth (Zevenbergen, 2004).

The initial pattern of work will involve patterns of different colors or shapes. Experience with patterns involving students: copy patterns that describe patterns of copying and extending patterns; and create and illustrate a pattern. Cognitive demands placed on students with increased activity of this pattern, so that the initial work must involve copying patterns and buildings large enough to create patterns. The initial experience with the pattern should consist of only two items in one attribute (Zevenbergen, 2004).

Problem-solving by finding patterns is part of the first heuristic strategy (Larson, 1983; Sickafus, 2004). The pattern of Problem-solving can be found by students more than one solution by developing existing patterns or with other concepts that help find Problem-solving patterns.

One form of heuristic breaking strategy describes such as climbing a hill by providing a general framework for understanding transformation and providing insight into Problem-solving. The final solution decreases as a form of part of the in the process requires algebraic thinking, both of which seek recursive similarities in phenomenology of insight. Patterns also provide a basis for early algebraic thinking Experience by repeating it and growing patterns can develop functionally. Thinking when students stepped into a simpler single data set to find the relationship between data sets (Warren \& Cooper, 2006, in Papic, 2007). Warren and Cooper (2006, in Papic, 2007) recommend that the pattern is presented in a variety of different modes such as with action, music or geometric shapes. This increases the potential of the generalization pattern as a loop unit regardless of model.

Similarly, patterns can be represented and sent in different ways, thus creating the potential for early algebraic thinking (Papic, 2007). Geometric growth patterns are often used in primary schools, teaching is not always structured in a way that best supports the development of students functional thinking. geometric growth patterns are often used in primary schools, teaching is not always structured in ways that best support the development of students' functional thinking (Markworth, 2012).

\section{Problem-solving strategy with "IDEAL"}

The steps of IDEAL (Bookhart, 2010) are easy to remember and useful for students and teachers. Students can use IDEAL steps to solve the problem. And for teachers, IDEAL analysis can help focus on one or more problem-solving tasks for teaching and assessment. Teachers can teach students how to identify problems and why they matter. Teachers can also specifically use assessment tasks that require students to identify problems (Boorkhart, 2010)

According to Bransford and Stein (1984, in Bookhart, 2010) there are five 
stages of "IDEAL" in classifying problemsolving skills described as follows:

a. Identify the problem to solve To assess the ability of problem identification to be solved, it will be measured ability:

1) expressing questions in terms of language and subject matter concepts of mathematics to be solved

2) express by writing down what is known and what is asked correctly and clearly,

3) write down the steps that will be used to solve them (Bookhart, 2010)

Identifying or defining a problem is the first step to solve it. This step is very similar to "focus on the main question or idea" type of task assigned. To assess the identification of the problem, point out the scenario or description of the problem and ask the student to identify the problem that needs to be solved. Or present a statement that contains the problem and asks students to ask questions that need to be answered in order to solve the problem (Bookhart, 2010).

b. Define and illustrate the problem

Explain can be done by using illustrations using symbols, or by using short sentences or with a picture scheme that can clarify the problem to be split along with the solution in a sketch image.

c. Investigate possible strategies

Some important things to consider in choosing the problem-solving stratregy according to Brokhart (2010):

1) Select some different strategies that can be used to solve a problem.

2) Prioritize strategies according to selected criteria for specific issues (eg most efficient, most effective, least expensive, etc.), before experimenting with some of these criteria and determining the best strategy.

How to assess how students describe some troubleshooting strategies by Bookhart (2010):

1) state a problem;

2) have students solve problems in two or more ways;

3) show the solution using drawings, diagrams, or graphs or;

4) state the problem of two or more acceptable strategies for solving them and;

5) have students explain why both strategies are true.

d. Doing strategy

In undertaking the strategy is only demanded which relates to each student's skill about the chosen strategy. Another thing to note is the thoroughness in doing the strategy.

e. Re-check and evaluate your activity effects

You can assess how students evaluate the quality of the solution in several ways. One is to ask students to produce several different solutions. Another way is to provide some solutions to the students and ask them to evaluate the solution. If you provide solutions to be evaluated, be sure to change their correctness and quality so that students can demonstrate their ability to evaluate. Bookhart (2010)

\section{CONCLUSION}

The conclusions of this study are as follows.

1. Profile of student Problem-solving ability in finding patterns through "IDEAL" strategy can help facilitate algebra Problem-solving, depicted from 20 groups of students able to do 2 kinds of solution solving. 
2. There are four patterns of Problemsolving that students can form three types of patterns similar to Larson's solution pattern on the 1st, 2nd, 4th, and one other solution in the form of geometric sequence patterns.

3. 3 groups have 3 types of solutions consisting of:

a. 1 group has solution 1 , solution 2, and solution 4 ;

b. 1 group has solution 1 , solution 4 , and other solution but wrong;

c. 1 group has solution 1 , solution 2, and other correct solution (other solution made by geometry line).

\section{REFERENCE}

Anderson, J. R. (2012). Tracking Problemsolving by Multivariate Pattern Analysis and Hidden Markov Model Algorithms. Neuropsychologia, v50 n4 , P487-498 Maret.

Balk, G. (1971). Application of Heuristic Methods to the Study of Mathematics at School . Educational Studies in Mathematics 3, D.Reidel Publishing Company (pp. 133-146). DordrechtHolland: D.Reidel Publishing Company.

Bookhart, S. M. (2010). Assess HigherOrder Thinking Skill in Your Classroom. Virginia USA: Alexandria.

Bransford John D., S. B. (1993). The Ideal Problem Solver. New York: W.H. Freeman and Company.

Chronicle, E. P., MacGregor, J. N., \& Ormerod, T. C. (Januari 2004). What Makes an Insight Problem? The Roles of Heuristics, Goal Conception, and Solution Recoding in Knowledge-Lean Problems . Journal of Experimental Psychology: Learning, Memory, and Cognition, v30 n1, p14-27.
Counting, G. P. (Nov 2012). Growing Patterns: Seeing beyond Counting. Teaching Children Mathematics, v19 n4 , p254-262.

Decker, S. L., \& Roberts, A. M. ( May 2015). Specific Cognitive Predictors of Early Math Problem-solving. Psychology in the Schools, V52 n5, p477-488.

Kribbs, E., \& Rogowsky, B. (Winter 2016 ). A Review of the Effects of VisualSpatial Representations and Heuristics on Word Problem-solving in Middle School Mathematics. International Journal of Research in Education and Science, Volume 2, Issue 1, ISSN: 2148-9955, 65-74.

Kusumadewi. (2005). Penenyelesaian Masalah Optimasi dengan Teknikteknik Heuristik. Yogyakarta: Graha Ilmu.

Larson, L. C. (1983). Problem-Solving Through Problems. New York: Springer-Verlag.

Markworth, K. A. (2012). Growing Patterns: Seeing beyond Counting. Teaching Children Mathematics, $v 19$ $n 4, \mathrm{p} 254-262$.

Meagher Michael, E. M.-K. (2013). The Shift From "Learner/Doer of Mathematics" to "Teacher of Mathematics": A Heuristic for Teacher Candidates. Mathematics Teacher Education and Development Vol.15 No.1 , 88-107.

Middleton, J. A. (2015). Large-Scale Studies Mathematics Educations. In Curriculum, A Lesson for the Common Core Standards Era: The Importance of Considering School-Level Buy-in When Implementing and Evaluating Standards-Based Instructional Materials. USA: Springer.

Mutakhiroh. (2007). Pemanfaatan Metode Heuristik Dalam Pencarian Rute 
Terpendek dengan Algoritma Semut dan Algoritma Genetika. SNATI, B33B39.

Nurfuadah, R. N. (2015, Januari Jumat). Kepribadian Turut Tentukan Prestasi Akademik. Retrieved Agustus Kamis, 2015 , from rifanadiaNurfuadah.yahoo.com.

Orton, A. (2006). Learning Mathematics. London-New York: Continuum.

Reigeluth, C. M., Lee, J.-Y., Peterson, B., \& Chavez, M. (2003). Formative Research on the Heuristic Task Analysis Process. ERIC Clearinghouse on Information \& Technology @Syracuse University621 Skytop Road, Ste 160Syracuse, NY 13244$5290,1-48$.

Savitri, P. (2015). Review Desain Interface Aplikasi SOPPPOS Menggunakan Evaluasi Heuristik. Jurnal SIMETRI, 95-100.
Wilkie, K. J., \& Clarke, D. M. (Jun 2016). Developing Students' Functional Thinking in Algebra through Different Visualisations of a Growing Pattern's Structure6. Mathematics Education Research Journal, v28 n2 , p223-243.

Wismath, S. L., \& Orr, D. (November 2015). Collaborative Learning in Problem-solving: A Case Study in Metacognitive Learning. The Canadian Journal for the Scholarship of Teaching and Learning Volume $6 \mid$ Issue 3 , 1-17.

Yetter, G., Gutkin, T. B., Saunders, A., Galloway, A. M., Sobansky, R. R., \& Song, S. Y. (2006). Unstructured Collaboration versus Individual Practice for Complex Problem-solving: A Cautionary Tale. Journal of Experimental Education, v74 n2, p137-159. 
70 JURNAL PENDIDIKAN EDUTAMA, Vol.5, No.1 Januari 2018 